\title{
Contribution Linkage and Role of Village Apparatus in Village Finance Management to Achieve Accountability of Village Revenue Expenditure Budget
}

\author{
Karmawan $^{1}$ and Dony Yanuar $^{2}$ \\ ${ }^{1}$ Departement of Accountancy, Faculty of Economic, University of Bangka Belitung \\ ${ }^{2}$ Department of Management, Faculty of Economic, University of Bangka Belitung \\ Karmawan77@gmail.com
}

\begin{abstract}
This Empirical Research aims to look at the contribution and role of Management Village Finance by village apparatus, overall activities including planning, Implementation, administration, reporting and accountability of village finances and Funds Villages sourced from the State Revenue and Expenditure Budget are designated For villages transferred through the District / City Revenue and Expenditure Budget And used to finance the administration, development, Community development, and community empowerment based on Ministerial Regulation Internal Affair of Ministry Number 113 of 2014. The results of this study are expected to contribute to the device Village in district of West Bangka Regency about Strategies to create financial statements and manage a good budget, deliver Training on information technology for village apparatus, training documenting ways and orderly administration and ways of making numbers/codes and codes Documents / archives and others. The population in this study is all of the villages in Mentok and Parit Tiga District of West Bangka Regency while the sample in this study are geographically located villages in Mentok and Parit Tiga Districts of West Bangka Regency. This study uses Primary Data in the form of interviews and Secondary Data taken directly from Object of Research with statistics test. Descriptive and Quantitative Test Correlation (relationship) with Pearson Correlation between research variable.
\end{abstract}

Keywords: Contributions, Role of Village Apparatus, Village Finance Management, Accountability, Village of Revenue and Expenditure Budget.

\section{Pendahuluan}

Proses Pengelolaan Keuangan Desa merupakan rangkaian keseluruhan kegiatan yang meliputi perencanaan, pelaksanaan, penatausahaan, pelaporan, dan pertanggungjawaban keuangan desa dan Dana Desa yaitu dana yang bersumber dari Anggaran Pendapatan dan Belanja Negara yang diperuntukkan bagi Desa yang ditransfer melalui Anggaran Pendapatan dan Belanja Daerah Kabupaten/Kota dan digunakan untuk membiayai penyelenggaraan pemerintahan, pelaksanaan pembangunan, pembinaan kemasyarakatan, dan pemberdayaan masyarakat.menurut Peraturan Menteri Dalam Negeri nomor 113 tahun 2014 terutama implementasinya pada beberapa desadesa yang ada di Kecamatan Mentok dan Kecamatan Parit Tiga di Kabupaten Bangka Barat.

Banyak pendapat dan persepsi dari Masyarakat awam biasanya mendeskripsikan Desa identik dengan masyarakatnya yang miskin, tradisionalis, dan kurang terpelajar, namun sebenarnya desa mempuyai keluhuran dan kearifan lokal yang luar biasa. Desa adalah pelopor sistem demokrasi 
yang otonom dan berdaulat penuh. Sejak lama, desa telah memiliki sistem dan mekanisme pemerintahan serta norma sosial masing-masing. Sampai saat ini pembangunan desa masih dianggap seperempat mata oleh pemerintah. Desa dalam Undang-Undang Nomor 22 Tahun 1999 tentang Pemerintah Daerah, bahwa desa adalah kesatuan masyarakat hukum yang memiliki kewenangan untuk mengatur dan mengurus kepentingan masyarakat setempat berdasarkan asalusul dan adat-istiadat setempat yang diakui dalam sistem Pemerintahan Nasional dan berada di Daerah Kabupaten, sedangkan dalam Undang-Undang Nomor 32 Tahun 2004 tentang Pemerintah Daerah, Desa adalah kesatuan masyarakat hukum yang memiliki batas-batas wilayah yang berwenang untuk mengatur dan mengurus kepentingan masyarakat setempat, berdasarkan asal-usul dan adat istiadat tempat yang diakui dan dihormati dalam sistem Pemerintahan Negara Kesatuan Republik Indonesia. Dalam persepktif sosiologis, desa adalah komunitas yang menempati wilayah tertentu dimana warganya saling mengenal satu sama lain dengan baik, bercorak homogen, dan banyak tergantung pada alam (Anwar dan Jatmiko, 2010).

Peraturan memberikan landasan bagi semakin otonomnya desa secara praktek, bukan hanya sekedar normatif. Dengan adanya pemberian kewenangan pengelolaan keuangan desa (berdasarkan Permendagri 37/ 2007) dan adanya alokasi dana desa (berdasarkan PP 72/2005), seharusnya desa semakin terbuka (transparan) dan responsibel terhadap proses pengelolaan keuangan. Dalam ketentuan umum Permendagri No.37 tahun 2007 juga disampaikan bahwa pengelolaan keuangan desa adalah keseluruhan kegiatan yang meliputi: perencanaan, penganggaran, penatausahaan, pelaporan, pertanggungjawaban dan pengawasan keuangan desa, sehingga dengan hak otonom tersebut diharapkan desa dapat mengelola keuangannya secara mandiri, baik mengelola pendapatan dan sumber-sumber pendapatan, juga mengelola pembelanjaan anggaran. Akan tetapi pada kenyataanya sangat banyak desa yang belum dapat memanfaatkan keistimewaanya tersebut, ketergantungan dana dari pemerintah pusat maupun pemerintah daerah sangat kuat.

Desa belum dapat mengoptimalkan sumber-sumber pendapatan desa dengan berbasis pada kekayaan dan potensi desanya. Penyusunan dan pelaksanaan Anggaran Pendapatan dan Belanja Desa (APBDes) yang seharusnya diisi dengan kegiatan/program-program yang dibutuhkan oleh masyarakat belum dapat diwujudkan, misalnya: kegiatan pembangunan fisik tersebut tidak dilaksanakan sesuai dengan yang tercantum di dalam APBDes, contoh adanya kecurangan terlihat mulai dari adanya perbedaan volume, kualitas, harga dan sebagainya. Kontribusi dari penelitian ini diharapkan mampu meningkatkan efisiensi, efektifitas dan ekonomis bagi perangkat desa dalam pengelolaan dana desa di Kecamatan Mentok dan Kecamatan Parit Tiga Kabupaten Bangka Barat serta dapat dijadikan bahan pertimbangan dan masukan terkait perencanaan, program dan juga evaluasi terkait perkembangan daerah.

Berbagai penelitian tentang fenomena tersebut di atas sudah dilakukan oleh beberapa diantaranya Putriyanti (2012). Hasil penelitian ini menunjukkan bahwa penerapan otonomi desa di Desa Aglik memuat tiga agenda pokok yaitu kewenangan desa, perencanaan pembangunan desa, dan keuangan desa. Penguatan akuntabilitas pemerintahan Desa Aglik dilakukan melalui tiga bentuk pertanggungjawaban yaitu Laporan Penyelenggaraan Pemerintah Desa kepada Bupati, Laporan Pertanggungjawaban Kepala Desa kepada BPD, dan Informasi Laporan Penyelenggaraan Pemerintahan Desa kepada Masyarakat. Penguatan pemberdayaan masyarakat desa di Desa Aglik dilakukan melalui program PNPM Mandiri Pedesaan, Kelompok Tani, Kelompok Ternak, 
dan pembuatan pupuk organik dan masih kurang tanggapnya masyarakat terhadap informasi Laporan Penyelenggaraan Desa serta kurangnya pengawasan terhadap pertanggungjawaban pemerintah desa merupakan kendala dalam menguatkan akuntabilitas pemerintahan Desa Aglik. Sedangkan dalam hal penguatan pemberdayaan masyarakat desa, tidak adanya pembukuan atas penyelenggaraan program serta kurangnya sosialisasi kepada masyarakat atasprogram yang dicanangkan merupakan kendala utama yang dihadapi dalam proses pemberdayaan masyarakat di Desa Aglik.

Furqani (2010) dari hasil penelitiannya tentang manajemen keuangan dari Desa Kalimo Kecamatan Kalianget Kabupaten Sumenep, transparansi terjadi hanya ketika perencanaan saja. Hampir semua proses tidak memenuhi prinsip tanggung jawab karena ada beberapa hal dalam proses yang tidak sesuai dengan Permendagri Nomor 37/2007. Sementara akuntabilitas sangat rendah karena tanggung jawab tidak melibatkan masyarakat dan BPD (Badan Permusyawaratan Desa/Badan Permusyawaratan Desa) sedangkan Anwar dan Jatmiko (2010) dapat menjelaskan bahwa pemerintahan desa telah memperhatikan kesejahteraan desa serta dalam memperlakukan keseluruh masyarakat dilakukan secara adil dan bijak. Penelitian ini merupakan pengembangan dari beberapa penelitian yang sudah dijelaskan sebelumnya untuk di terapkan di Desa-Desa Kecamatan Mentok dan Kecamatan Parit Tiga Kabupaten Bangka Barat.

\section{Kajian Pustaka}

\section{Anggaran}

Berdasarkan Peraturan Pemerintah (PP) Nomor 71 Tahun 2010 tentang Standar Akuntansi Pemerintahan (SAP), menerangkan bahwa anggaran merupakan pedoman tindakan yang akan dilaksanakan pemerintah meliputi rencana pendapatan, belanja, transfer, dan pembiayaan yang diukur dalam satuan rupiah, yang disusun menurut klasifikasi tertentu secara sistematis untuk suatu periode. Menurut Nordiawan (2006) Anggaran merupakan sebuah rencana financial yang menyatakan rencana-rencana organisasi untuk melayani masyarakat atau aktivitas lain dapat mengembangkan kapasitas organisasi dalam pelayanan, estimasi besarnya biaya yang harus dikeluarkan dalam merealisasikan rencana tersebut, perkiraan sumber-sumber mana saja yang akan menghasilkan pemasukan serta seberapa besar pemasukan tersebut. Menurut Halim (2007) anggaran (budget) adalah suatu rencana operasional yang dinyatakan dalam suatu uang dari suatu organisasi, dimana suatu pihak menggambarkan perkiraan pendapatan atau penerimaan guna menutupi pengeluaran tersebut untuk periode tertentu yang umumnya satu tahun. Menurut Munandar (2001) Anggaran adalah suatu rencana yang disusun secara sistematis yang meliputi seluruh kegiatan perusahaan, yang dinyatakan dalam unit (kesatuan) moneter dan berlaku untuk jangka waktu (periode) tertentu yang akan datang.

Berbagai pengertian anggaran yang telah dikemukakan, maka dapat disimpulkan bahwa anggaran merupakan sebuah proses yang dilakukan oleh organisasi sektor publik untuk dijadikan pedoman atas rencana-rencana organisasi untuk melayani masyarakat atau aktivitas lain dapat mengembangkan kapasitas organisasi dalam pelayanan, meliputi rencana pendapatan, belanja, transfer, dan pembiayaan yang diukur dalam satuan rupiah yang disusun menurut klasifikasi tertentu secara sistematis untuk suatu periode. Sedangkan menurut Adisaputo dan Asri (2003) anggaran merupakan suatu pendekatan yang formal dan sistematis daripada pelaksanaan tanggung jawab manajemen di dalam perencanaan, koordinasi dan pengawasan. Dari pengertian di atas dapat diambil kesimpulan yaitu: (a) Bahwa anggaran harus bersifat formal, artinya bahwa 
anggaran disusun dengan sengaja dan bersungguh-sungguh dalam bentuk tertulis. (b) Bahwa anggaran harus bersifat sistematis, artinya bahwa anggaran disusun dengan berurutan dan berdasarkan suatu logika, (c) Bahwa setiap saat manajer dihadapkan pada suatu tanggung jawab untuk mengambil keputusan, sehingga anggaran merupakan suatu hasil pengambilan keputusan yang berdasar beberapa asumsi tertentu, (d) Bahwa keputusan yang diambil oleh manajer tersebut merupakan pelaksanaan fungsi manajer dari segi perencanaan, koordinasi dan pengawasan.

\section{Transparansi}

Salah satu unsur utama dalam pelaporan keuangan pemerintahan adalah transparansi. Transparansi artinya dalam menjalankan pemerintahan, pemerintah mengungkapkan hal-hal yang sifatnya material secara berkala kepada pihak-pihak yang memiliki kepentingan untuk itu, dalam hal ini yaitu masyarakat luas. Menurut Mardiasmo (2010), pengertian transparansi adalah "Keterbukaan Pemerintah dalam membuat kebijaksanaan-kebijaksanaan keuangan daerah sehingga dapat diketahui dan diawasi oleh DPRD dan masyarakat". Menurut Nordiawan (2006) menyatakan "Transparansi memberikan informasi keuangan yang terbuka dan jujur kepada masyarakat berdasarkan pertimbangan bahwa masyarakat memiliki hak untuk mengetahui secara terbuka dan menyeluruh atas pertanggung-jawaban pemerintah dalam pengelolaan sumber daya yang dipercayakan kepadanya dan ketaatannya pada peraturan perundang-undangan”. Dari uraian tersebut dapat diambil kesimpulan, bahwa transparansi suatu negara dapat tercipta apabila sistem pemerintahan negara tersebut memberikan kebebasan bagi masyarakatnya untuk memperoleh informasi yang dibutuhkan oleh masyarakat luas.

\section{Akuntabilitas}

Tata kelola pemerintahan yang baik merupakan salah satu tuntunan masyarakat yang harus dipenuhi. Salah satu pilar tata kelola tersebut adalah akuntabilitas. Sabeni dan Ghozali (2001) menyatakan "Akuntabilitas atau pertanggungjawaban (accountability) merupakan suatu bentuk keharusan seseorang (pimpinan/pejabat/pelaksana) untuk menjamin bahwa tugas dan kewajiban yang diemban nya sudah dilaksanakan sesuai ketentuan yang berlaku. Akuntabilitas dapat dilihat melalui laporan tertulis yang informatif dan transparan". Mardiasmo (2010) mengatakan "Akuntabilitas publik adalah kewajiban pihak pemegang amanah untuk memberikan pertanggungjawaban, menyajikan dan mengungkapkan segala aktivitasnya dan kegiatan yang menjadi tanggung jawabnya kepada pihak pemberi amanah (Principal) yang memiliki hak dan kewenangan untuk meminta pertanggung-jawaban tersebut". Menurut Nordiawan (2006) mengatakan "Akuntabilitas adalah mempertanggungjawabkan pengelolaan sumber daya serta pelaksanaan kebijakan yang dipercayakan kepada entitas pelaporan dalam mencapai tujuan yang telah ditetapkan secara periodik". Seperti yang telah dijabarkan, dari beberapa definisi tersebut menurut Mardiasmo (2010) menjelaskan terdapat lima dimensi akuntabilitas yang harus dipenuhi oleh organisasi sektor publik, yaitu: (1) Akuntabilitas Keuangan, Akuntabilitas keuangan terkait dengan penghindaran penyalahgunaan dana publik; (2) Akuntabilitas Kejujuran dan Akuntabilitas Hukum, akuntabilitas kejujuran terkait dengan penghindaran penyalahgunaan jabatan, sedangkan akuntabilitas hukum terkait dengan jaminan dengan adanya kepatuhan terhadap hukum dan peraturan lain yang diisyaratkan dalam penggunaan sumber dana publik; (3) Akuntabilitas Proses, akuntabilitas proses terkait dengan apakah prosedur yang digunakan dalam melaksanakan tugas sudah cukup baik dalam hal kecukupan sistem informasi akuntansi, sistem informasi manajemen dan prosedur administrasi; (4) Akuntabilitas Program, akuntabilitas 
program terkait dengan pertimbangan apakah tujuan dapat ditetapkan dapat dicapai atau tidak, dan apakah telah mempertimbangkan alternative program yang memberikan hasil yang optimal dengan biaya yang minimal; (5) Akuntabilitas Kebijakan, akuntabilitas kebijakan terkait dengan pertanggung-jawaban Pemerintah, baik Pusat maupun daerah atas kebijakan-kebijakan yang diambil pemerintah terhadap DPR/DPRD dan masyarakat luas. Berdasarkan beberapa definisi di atas mengenai pengertian akuntabilitas maka pemerintah pusat maupun pemerintah daerah diharapkan dapat menyajikan laporan keuangan yang terdiri atas Surplus/Defisit, LRA, Neraca dan CaLK. Laporan keuangan tersebut merupakan komponen penting untuk menciptakan akuntabilitas sektor publik dan merupakan salah satu alat ukur kinerja Financial Pemerintah Pusat dan Pemerintah daerah.

\section{Pemerintahan Desa}

Desa adalah kesatuan masyarakat hukum yang memiliki kewenangan mengatur dan mengurus kepentingan masyarakat setempat berdasarkan asal-usul dan adat-istiadat setempat yang diakui dalam sistem pemerintahan nasional dan berada di daerah Kabupaten dalam Widjaya HAW, (2003), rumusan definisi Desa secara lengkap terdapat dalam Undang-Undang No.22/1999 tentang Pemerintah daerah: "Desa atau yang disebut dengan nama lain sebagai satu kesatuan masyarakat hukum yang mempunyai susunan asli berdasarkan hak asal-usul yang bersifat istimewa sebagaimana yang dimaksud dalam penjelasan pasal 18 UUD 1945. Landasan pemikiran dalam pengaturan Pemerintahan Desa adalah keanekaragaman, partisipasi, otonomi asli, demokratisasi dan pemberdayaan masyarakat”. Desa dalam Undang-Undang Nomor 22 Tahun 1999 tentang Pemerintah Daerah, bahwa desa adalah kesatuan masyarakat hukum yang memiliki kewenangan untuk mengatur dan mengurus kepentingan masyarakat setempat berdasarkan asal-usul dan adat-istiadat setempat yang diakui dalam sistem Pemerintahan Nasional dan berada di Daerah Kabupaten. Sedangkan dalam Undang-Undang Nomor 32 Tahun 2004 tentang Pemerintah Daerah, Desa adalah kesatuan masyarakat hukum yang memiliki batasbatas wilayah yang berwenang untuk mengatur dan mengurus kepentingan masyarakat setempat, berdasarkan asal-usul dan adat istiadat tempat yang diakui dan dihormati dalam sistem Pemerintahan Negara Kesatuan Republik Indonesia.

\section{Pengelolaan Keuangan Desa}

Pengelolaan Keuangan Desa yaitu keseluruhan kegiatan yang meliputi perencanaan, pelaksanaan, ketatausahaan, pelaporan, dan pertanggungjawaban keuangan desa serta Dana Desa yang bersumber dari Anggaran Pendapatan dan Belanja Negara yang diperuntukkan bagi Desa yang ditransfer melalui Anggaran Pendapatan dan Belanja Daerah Kabupaten/Kota dan digunakan untuk membiayai penyelenggaraan pemerintahan, pelaksanaan pembangunan, pembinaan kemasyarakatan, dan pemberdayaan masyarakat, menurut Peraturan Menteri Dalam Negeri Nomor 113 tahun 2014.

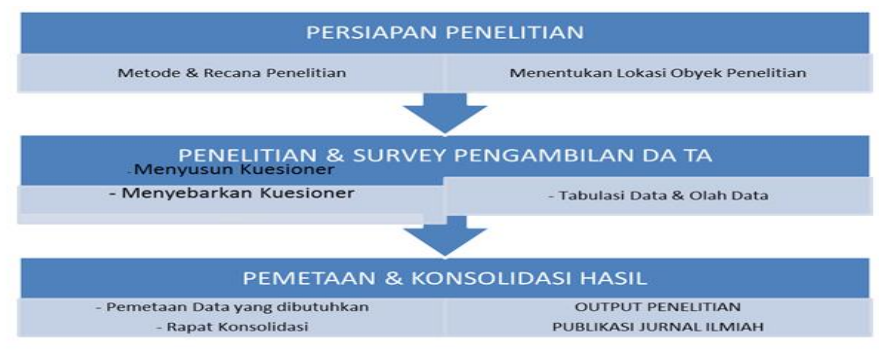

Gambar 1. Rerangka Berpikir 
IJBE: Integrated Journal of Business and Economics

e-ISSN: 2549-3280

\section{Metode Penelitian}

\section{Populasi}

Populasi dalam penelitian ini adalah Seluruh Desa yang ada di Kecamatan Mentok dan Kecamatan Parit Tiga Kabupaten Bangka Barat Sedangkan sampel dalam penelitian ini adalah Desa-desa yang letak geografisnya ada di Kecamatan Mentok dan Kecamatan Parit Tiga Kabupaten Bangka Barat Hal ini dilakukan karena Desa-desa tersebut pertimbangannya menerima dan juga mengelola Dana Desa.

\section{Sampel}

Menurut Sugiyono (1999) sampel adalah bagian dari jumlah dan karakteristik yang dimiliki oleh populasi tersebut. Sampel yang diambil dari populasi harus betul-betul representatif (mewakili). Sedangkan untuk pengambilan sampel teknik yang digunakan adalah Sampel dipilih dengan menggunakan metode purposive sampling dimana populasi yang akan dijadikan sampel penelitian adalah populasi yang memenuhi kriteria sampel tertentu. Kriteria-kriteria tersebut adalah Desa - Desa di Kecamatan yang dijadikan obyek penelitian tersebut sudah menerima dan mengelola Alokasi Dana Desa baik dari Pemerintah Daerah dan Pemerintah Pusat yaitu Kementerian terkait.

\section{Metode Pengumpulan Data}

Penelitian ini menggunakan Data Primer berupa wawancara dan Data Sekunder yang diambil langsung dari Obyek Penelitian. Metode pengumpulan data lainnya yang digunakan adalah studi pustaka yaitu melalui jurnal, buku teks, artikel, dan sumber-sumber tertulis lainnya yang masih berkaitan dengan topik penelitian ini.

\section{Metode Analisis Data}

Metoda analisis data yang digunakan dalam penelitian ini menggunakan analisis Statistik Deskriptif \& Uji Kuantitatif. Statistik deskriptif merupakan metode untuk mengumpulkan, mengolah, menyajikan, dan menganalisa data kuantitatif secara deskriptif. Statistik deskriptif memberikan gambaran atau deskripsi dari suatu data yang dilihat dari nilai rata-rata (mean), standar deviasi, varian, maksimum, minimum, sum, range, kurtosis, dan skewness (kemencengan distribusi) dan Uji Kuantitatif Korelasi (hubungan) dengan Pearson Correlation antar Variabel Penelitian (Ghozali, 2013).

\section{Pembahasan Hasil}

Karakteristik responden dalam penelitian ini dibagi menjadi 2 kategori yaitu karakteristik responden berdasarkan jenis kelamin dan karakteristik responden berdasarkan tingkat pendidikan terakhir. Karakteristik responden berdasarkan jenis kelamin dapat dilihat pada tabel berikut ini:

Tabel 1. Karakteristik Responden Menurut Jenis Kelam
\begin{tabular}{|c|c|c|}
\hline Jenis Kelamin & Total & Persentase (\%) \\
\hline Laki-laki & 20 & 44.5 \\
\hline Perempuan & 25 & 55.5 \\
\hline Total & 45 & 100 \\
\hline
\end{tabular}

Sumber : Data Primer diolah, 2017 
Tabel 1. menunjukkan bahwa persentase responden pria adalah 44,5\% dan persentase responden wanita adalah 55,5\%. Karakteristik responden berdasarkan tingkat pendidikan terakhir dalam penelitian ini terbagi dalam tiga tingkatan, yaitu Sarjana S1 dan SMA. Jumlah tingkat pendidikan dapat dilihat pada tabel berikut ini:

Tabel 2. Karakteristik Responden Berdasarkan Pendidikan

\begin{tabular}{|c|c|c|}
\hline Tingkat Pendidikan & Total & Persentase (\%) \\
\hline S1 & 12 & 26.7 \\
\hline Diploma & 18 & 40.0 \\
\hline SLTA & 15 & 33.3 \\
\hline Total & $\mathbf{4 5}$ & $\mathbf{1 0 0}$ \\
\hline
\end{tabular}

Sumber : Data Primer diolah, 2017

Tabel 2. menunjukkan bahwa jumlah responden dengan tingkat pendidikan terakhir adalah Sarjana 12 orang atau sebanyak 26,7\%, jumlah responden dengan tingkat pendidikan SLTA adalah 15 orang atau 33,3\%, dan jumlah responden dengan tingkat pendidikan Diploma adalah 18 orang atau $40,0 \%$.

Dalam pembahasan ini, peneliti menekankan dampak alat analisis korelasi, yaitu peneliti meneliti hubungan antara variabel yang akhirnya peneliti dapat menentukan faktor yang paling dominan, sedangkan untuk mengetahui hasil korelasi dapat dilihat dengan rangking berikut. :

\section{Tabel 3. Tingkat Korelasi Koefisien}

\begin{tabular}{|c|c|}
\hline Koefisien & Tingkat Korelasi \\
\hline 0 & Tidak berkorelasi \\
\hline $0.01-0.20$ & Sangat rendah \\
\hline $0.21-0.40$ & Rendah \\
\hline $0.41-0.60$ & Moderat \\
\hline $0.61-0.80$ & Kuat \\
\hline $0.81-0.99$ & Sangat Kuat \\
\hline 1 & Sempurna \\
\hline
\end{tabular}

Berdasarkan hasil pengolahan data, dapat disimpulkan bahwa kontribusi dan peran aparat desa di kecamatan Mentok dan Parit Tiga Kabupaten Bangka Barat dapat dijelaskan hanya 20\% aparatur desa yang berkontribusi dan berkontribusi dalam pengelolaan dana kelurahan. Sedangkan dari variabel perencanaan, dapat diketahui bahwa Aparatur Desa yang ada di Kabupaten Mentok dan Kabupaten Parit Tiga Kabupaten Bangka Barat dari sisi perencanaan dijelaskan 15,98\% Aparatur Desa yang terlibat dalam Pengelolaan Dana Desa. Sebanyak 46,42\% Aparat Desa di Kecamatan Mentok dan Parit Tiga di Bangka Barat telah menerapkan anggaran sesuai dengan Akuntabilitas Pengelolaan Dana Desa. 
IJBE: Integrated Journal of Business and Economics e-ISSN: 2549-3280

Tabel 4. Descriptive Statistics

\begin{tabular}{|c|c|c|c|}
\hline \multicolumn{3}{|c|}{ Descriptive Statistics } \\
\hline & Mean & $\begin{array}{c}\text { Std. } \\
\text { Deviation }\end{array}$ & $\mathrm{N}$ \\
\hline $\begin{array}{c}\text { Kontribusi dan Peran Perangkat } \\
\text { Desa }\end{array}$ & 19,20 & 3,507 & 45 \\
$\begin{array}{c}\text { Perencanaan (Akuntabilitas } \\
\text { Pegelolaan Dana Desa) }\end{array}$ & 15,98 & 3,558 & 45 \\
$\begin{array}{c}\text { Pelaksanaan (Akuntabilitas } \\
\text { Pegelolaan Dana Desa) }\end{array}$ & 46,42 & 5,163 & 45 \\
$\begin{array}{c}\text { Penatausahaan (Akuntabilitas } \\
\text { Pegelolaan Dana Desa) }\end{array}$ & 12,89 & 1,824 & 45 \\
$\begin{array}{c}\text { Pelaporan (Akuntabilitas Pegelolaan } \\
\text { Dana Desa) }\end{array}$ & 22,98 & 3,454 & 45 \\
$\begin{array}{c}\text { Pertanggungjawaban (Akuntabilitas } \\
\text { Pegelolaan Dana Desa) }\end{array}$ & 12,42 & 1,617 & 45 \\
\hline
\end{tabular}

Sumber : Data Primer diolah, 2017

Dalam hal Administrasi Akuntabilitas Pengelolaan Dana Desa berdasarkan hasil hanya 12,89\% aparatur desa yang sudah melaksanakan pengelolaan administrasi keuangan dengan baik. Dalam hal Pelaporan Akuntabilitas Pengelolaan Dana Desa berdasarkan hasil 22,98\% Aparat Desa yang ada telah menerapkan Pelaporan Keuangan Desa Fund dengan baik. Sedangkan pertanggungjawaban dapat disimpulkan bahwa $12.42 \%$ Perangkat Desa telah dilaksanakan dengan baik untuk mewujudkan Dana Pengelolaan Akuntabilitas Desa di Kabupaten Mentok dan Kabupaten Parit Tiga Kabupaten Bangka Barat.

Tabel 5. Pearson Correlation Analysis

\begin{tabular}{|c|c|c|c|c|c|c|c|}
\hline \multicolumn{8}{|c|}{ Correlations } \\
\hline & & $\begin{array}{c}\text { Kontribusi } \\
\text { dan Peran } \\
\text { Perangkat } \\
\text { Desa }\end{array}$ & \begin{tabular}{|c|} 
Perencanaan \\
(Akuntabilitas \\
Pegelolaan \\
Dana Desa) \\
\end{tabular} & \begin{tabular}{|c|} 
Pelaksanaan \\
(Akuntabilitas \\
Pegelolaan \\
Dana Desa) \\
\end{tabular} & $\begin{array}{c}\text { Penatausahaan } \\
\text { (Akuntabilitas } \\
\text { Pegelolaan } \\
\text { Dana Desa) }\end{array}$ & \begin{tabular}{|c|} 
Pelaporan \\
(Akuntabilitas \\
Pegelolaan \\
Dana Desa) \\
\end{tabular} & $\begin{array}{c}\text { Pertanggungjawaban } \\
\text { (Akuntabilitas } \\
\text { Pegelolaan Dana } \\
\text { Desa) }\end{array}$ \\
\hline \multirow[t]{3}{*}{$\begin{array}{l}\text { Kontribusi dan Peran } \\
\text { Perangkat Desa }\end{array}$} & \begin{tabular}{|l} 
Pearson \\
Correlation
\end{tabular} & 1 & $.620^{-}$ & $.622^{-}$ & $.533^{-}$ & $.625^{-}$ & .518 \\
\hline & Sig. (2-tailed) & & 0,000 & 0,000 & 0,000 & 0,000 & 0,000 \\
\hline & $\mathrm{N}$ & 45 & 45 & 45 & 45 & 45 & 45 \\
\hline \multirow{3}{*}{$\begin{array}{l}\text { Perencanaan } \\
\text { (Akuntabilitas } \\
\text { Pegelolaan Dana } \\
\text { Desa) }\end{array}$} & \begin{tabular}{|l|} 
Pearson \\
Correlation
\end{tabular} & $.620^{-}$ & $\overline{1}$ & $.655^{-}$ & $.409^{-}$ & $.429^{-}$ & .381 \\
\hline & Sig. (2-tailed) & 0,000 & & 0,000 & 0,005 & 0,003 & 0,010 \\
\hline & $\mathrm{N}$ & 45 & 45 & 45 & 45 & 45 & 45 \\
\hline \multirow{3}{*}{$\begin{array}{l}\text { Pelaksanaan } \\
\text { (Akuntabilitas } \\
\text { Pegelolaan Dana } \\
\text { Desa) }\end{array}$} & \begin{tabular}{|l|} 
Pearson \\
Correlation
\end{tabular} & $.622^{-}$ & $.655^{-}$ & 1 & $.731^{-}$ & $.634^{-}$ & .681 \\
\hline & Sig. (2-tailed) & 0,000 & 0,000 & & 0,000 & 0,000 & 0,000 \\
\hline & $\mathrm{N}$ & 45 & 45 & 45 & 45 & 45 & 45 \\
\hline \multirow{3}{*}{$\begin{array}{l}\text { Penatausahaan } \\
\text { (Akuntabilitas } \\
\text { Pegelolaan Dana } \\
\text { Desa) }\end{array}$} & \begin{tabular}{|l} 
Pearson \\
Correlation
\end{tabular} & $.533^{-1}$ & $.409^{-}$ & $.731^{-}$ & 1 & $.528^{-}$ & $.895^{\circ}$ \\
\hline & Sig. (2-tailed) & 0,000 & 0,005 & 0,000 & & 0,000 & 0,000 \\
\hline & $\mathrm{N}$ & 45 & 45 & 45 & 45 & 45 & 45 \\
\hline \multirow{3}{*}{$\begin{array}{l}\text { Pelaporan } \\
\text { (Akuntabilitas } \\
\text { Pegelolaan Dana } \\
\text { Desa) }\end{array}$} & \begin{tabular}{|l} 
Pearson \\
Correlation
\end{tabular} & $.625^{\circ}$ & $.429^{-}$ & $.634^{-}$ & $.528^{-}$ & 1 & $.547^{7}$ \\
\hline & Sig. (2-tailed) & 0,000 & 0,003 & 0,000 & 0,000 & & 0,000 \\
\hline & $\mathrm{N}$ & 45 & 45 & 45 & 45 & 45 & 45 \\
\hline \multirow{3}{*}{$\begin{array}{l}\text { Pertanggungjawaban } \\
\text { (Akuntabilitas } \\
\text { Pegelolaan Dana } \\
\text { Desa) }\end{array}$} & \begin{tabular}{|l} 
Pearson \\
Correlation
\end{tabular} & $.518^{-}$ & $.381^{-}$ & $.681^{-}$ & $.895^{-}$ & $.547^{-1}$ & 7 \\
\hline & Sig. (2-tailed) & 0,000 & 0,010 & 0,000 & 0,000 & 0,000 & \\
\hline & $\mathrm{N}$ & 45 & 45 & 45 & 45 & 45 & 45 \\
\hline
\end{tabular}

Sumber : Data Primer diolah, 2017

Berdasarkan hasil Uji Korelasi Pearson diperoleh $r=0,620$ atau (hubungan kuat) antara, Kontribusi dan Peran Perangkat Desa dengan Perencanaan di APBD untuk mewujudkan 
Akuntabilitas Pengelolaan Dana Desa di Kecamatan Mentok dan Kabupaten Parit Tiga Kabupaten Bangka Barat. Sedangkan hubungan antara Perencanaan APBD dengan Implementasi diperoleh Nilai $\mathrm{r}=0,655$ atau (hubungan kuat), dalam upaya mewujudkan Akuntabilitas Pengelolaan Dana Desa. Variabel Implementasi hubungannya dengan Administrasi APBD diperoleh Nilai $\mathrm{r}=0,731$ atau (Relasi Kuat), dalam upaya mewujudkan Akuntabilitas Pengelolaan Dana Desa di Kabupaten Mentok dan Kabupaten Parit Tiga Kabupaten Bangka Barat. Hubungan antara Administrasi Variabel dengan Dana Akuntabilitas APBD memperoleh Nilai Korelasi $\mathrm{r}=0,895$ atau (Sangat Kuat) dalam mewujudkan Akuntabilitas Pengelolaan Dana Desa di Kabupaten Mentok dan Kabupaten Parit Tiga Kabupaten Bangka Barat.

\section{Kesimpulan dan Saran}

\section{Kesimpulan}

Berdasarkan hasil sebelumnya, dapat disimpulkan bahwa kontribusi dan peran aparatur desa di kecamatan Mentok dan Parit Tiga Kabupaten Bangka Barat sudah dalam perencanaan APBD, pelaksanaannya, administrasi dan akuntabilitas APBD Dana APBD juga baik. sedang berlangsung dalam mewujudkan Akuntabilitas Pengelolaan Dana Desa. Dari Hasil Perhitungan Hubungan Korelasi antara Variabel Administrasi dengan Akuntabilitas Dana APBD di Kecamatan Mentok dan Kabupaten Parit Tiga Kabupaten Bangka Barat Sangat Kuat dalam Mencapai Akuntabilitas Pengelolaan Dana Desa di Kecamatan Mentok dan Kabupaten Parit Tiga Kabupaten Bangka Barat .

\section{Keterbatasan}

Keterbatasan dalam penelitian ini hanya mengambil dua obyek Kecamatan saja di Kabupaten Bangka Barat, sehingga menyebabkan hasilnya belum begitu sempurna, Waktu dan Biaya juga menjadi masalah membatasi ruang, pergerakan dan waktu pelaksanaan studi ini.

\section{Saran}

Diharapkan peneliti lebih lanjut menambahkan obyek dan populasi dan sampel untuk memperbaiki penelitian ini.

\section{Referensi}

Abdullah, S. dan Halim, A. (2006). Studi atas Belanja Modal pada Anggaran Pemerintah dalam Hubungannya dengan Belanja Pemeliharaan dan Sumber Pendapatan. Jurnal Akuntansi Pemerintahan, 2(2), pp. 1-18.

Anwar, M. dan Jatmiko, B. (2010). Pengelolaan Keuangan Desa Untuk Mewujudkan Anggaran Pendapatan dan Belanja Desa Yang Transparan dan Akuntabel.

Putriyanti. A. (2012). Penerapan Otonomi Desa dalam Menguatkan akuntabilitas Pemerintahan Desa dan Pemberdayaan Masyarakat di Desa Aglik Kecamatan Grabag Kabupaten Purworejo. Yogyakarta: UNY.

Bastian, I. (2007). Sistem Akuntansi Sektor Publik. Edisi kedua. Jakarta: Salemba Empat 
Furqani, A. (2010). Tesis: Pengelolaan Keuangan Desa dalam Mewujudkan Good governance (Studi pada Pemerin-tahan Desa Kalimo'ok Kecamatan Kalianget Kabupaten Sumenep). Jatim: UPN.

Ghozali, I. (2013). Aplikasi Analisis Multivariate dengan Program IBM SPSS. 20, Edisi Keenam, Semarang: Badan Penerbit Universitas Diponegoro.

Halim, A. (2007). Akuntansi Keuangan Daerah. Jakarta: Salemba Empat.

Mardiasmo. (2010). Akuntansi Sektor Publik. Yogyakarta: CV. ANDI OFFSET.

Nordiawan, D. (2006). Akuntansi Sektor Publik. Jakarta: Salemba Empat.

Sabeni, A. dan Ghozali, I. (2001). Pokok-pokok Akuntansi Pemerintahan. Yogyakarta: BPFE.

Peraturan Menteri Dalam Negeri Nomor 37 Tahun 2007 tentang Pedoman Pengelolaan Pengelolaan Keuangan Desa.

Peraturan Pemerintah Republik Indonesia Nomor 22 tahun 2015 tentang Perubahan atas Peraturan Pemerintah No.60 Tahun 2014 Tentang Dana Desa yang berasal dari APBN.

Peraturan Pemerintah Republik Indonesia Nomor 58 tahun 2005 tentang Pengelolaan Keuangan Daerah.

Peraturan Menteri Dalam Negeri Nomor 59 Tahun 2007 tentang Perubahan atas Peraturan Menteri Dalam Negeri Nomor 13 Tahun 2006 tentang Pedoman Pengelolaan Keuangan Daerah.

Peraturan Pemerintah Republik Indonesia Nomor 71 tahun 2010 tentang Standar Akuntansi Pemerintahan.

Peraturan Pemerintah Republik Indonesia Nomor 72 tahun 2005 tentang Desa.

Peraturan Menteri Dalam Negeri Nomor 113 Tahun 2014 tentang Pengelolaan Keuangan Desa.

Undang-undang Otonomi Daerah, (1999:47). 